\title{
The Hollowing Out Phenomenon In Japan
}

Roblyn Simeon, (E-mail: rsimeon@sfsu.edu), San Francisco State University Yumi Ikeda, (E-mail: ikeday@hotmail.com), Consultant

\begin{abstract}
This paper examined the 'hollowing out' (de-industrialization) phenomenon in Japan. We collected time series data for twenty years to investigate the home country impact of outward FDI and a weakening manufacturing sector. We used descriptive statistics and econometric techniques to show that de-industrialization is indeed taking place. We also showed that domestic factors such as low inflation, high wage rates and an increasing number of firms were associated with a more dynamic manufacturing sector. However, the persistent unemployment and long recession point to the need for policies that will invigorate domestic industrial activity if Japan is to return to a strong growth path.
\end{abstract}

\subsection{Introduction}

he 'hollowing out' phenomenon is closely linked to three important economic concepts in the international business arena. These concepts are deindustrialization, economic restructuring, and globalization. Deindustrialization is the term generally used worldwide to describe the 'hollowing out' phenomenon. Both terms refer to the process whereby there is a significant reduction in the industrial capacity of a nation brought on by the increasing weakness of the domestic manufacturing sector (Modic and Trautlein 1985; Schnorbus and Giese 1987; Spilimbergo 1998).

This development is sometimes accompanied by a substantial restructuring of the domestic economy as labor and investments move from one sector to another. Some economists view this as a natural transformation of a mature economy as labor allocation and national productivity shift from agriculture to industry and then to services (Feinstein 1999; Iganski and Payne 1999). However, many other economists are concerned about the uncertain implications for overall economic growth, labor productivity and international competitiveness (Brada, Singh et al. 1994; Crafts 1996). Since globalization increases the interaction between nations and reduces the barriers to the free flow of capital and investments, it can both intensify and accelerate the 'hollowing out' experience (Robinson 1983; Trowbridge 1985).

In the literature on national competitiveness, 'hollowing out' is a major concern. Many economists consider a strong manufacturing sector as the engine for sustained economic growth. The main view is that as the manufacturing sector declines, there is a substantial loss of high paid manufacturing jobs. Although new jobs can be found in the service sector, they are usually at much lower wages with fewer chances for advancement (Davis and Huston 1992; Peck 1996). This development reduces consumers' buying power and demand levels for the overall economy. A major factor in the discussion of the 'hollowing out' phenomenon is the increasing freedom and flexibility that corporations have to move their production capacity to different locations around the world. Firms can avoid the impact of regulations, strong domestic currencies, land prices and high wages by moving to areas with cheaper labor, fewer regulations and more available land. The motivation for foreign direct investment (FDI) activities can thus provide an important insight into the potential impact of investment outflows on the domestic economy (Dreyfack and Port 1986; Terasaki and Yamauchi 1996).

Readers with comments or questions are encouraged to contact the authors via email. 


\subsection{The Case Of Japan}

The motivation and impact of FDI activities in Japan have changed over the postwar years. In the 1960s and 1970s, outward FDI was considered to have a positive impact on the Japanese economy. During this period, Japan faced the problems of rising energy prices, insufficient land for expansion and a shortage of labor. By relocating the labor and energy-intensive industries overseas, public and private investment in the manufacturing sectors focused on producing higher technology, value added products (Hirono,1996).

In the 1980s, more intense international competition led Japanese manufacturing industries to expand their FDI activities to take advantage of cheaper labor, land, and resources. However, exports continued to hold up well despite a strong yen and increasing FDI. Domestic manufacturing output also increased very quickly despite increasing FDI (Hirono, 1996). In the post bubble economy which started in the early 1990s, there has been a longer period of low and negative economic growth in Japan. This time there is increasing concern about the flow of outward FDI in the manufacturing sector and the potential negative impact on the overall economy.

This paper covers developments in the Japanese economy over the last twenty years. In general, the 1980's represent the high growth pre-bubble years and the 1990's reflect the low growth and recessionary post-bubble years of the Japanese economy. Some researchers in Japan have stated that 'hollowing out' could be good for the economy because it would boost labor productivity and force Japanese firms to innovate and develop higher value added products with more effective production processes. Others fear that a weaker manufacturing sector would not provide enough quality jobs and keep Japan on the path of economic stagnation (Hirono, 1996; Ishiyama, 1999). The objective of this paper is to use economic data and statistics to investigate three important issues as they relate to the developments in Japan:

- Has 'hollowing out' been occurring in Japan?

- What domestic factors might be affecting 'hollowing out' trends?

- How has 'hollowing out' impacted labor productivity and general employment levels?

\subsection{Literature Review}

The literature on the 'hollowing out' phenomenon usually covers three areas: the general deindustrialization process, home country and host country FDI outcomes. Those examining the deindustrialization process study the labor and investment shifts that accompany economic restructuring. The longer-term historical aspects of economic change are usually emphasized. Those writing about host country effects examine the impact of inward FDI on foreign economies. The studies on home country effects look at the impact on the domestic economy of an outflow of capital and investments due to outward FDI (Caulkin 1983; Robinson 1983; Terasaki and Yamauchi 1996). This paper is mainly concerned with the home country outcomes. However, we will briefly discuss the literature on host country impact of FDI before turning to home country outcomes.

\subsection{Host Country Impact}

The studies which investigated the impact of inward FDI on the host country economy were generally very positive. They point out that inward FDI definitely boosts the home country's GDP. Inward FDI also often has a positive effect on technical progress, total factor productivity, employment, the diffusion of new ideas and new technologies (Radulescu 1996; Hirono 1996; Barrell and Pain 1997 and 1999,). Dunning (1984) states that due to Japanese FDI in the UK, the general level of performance and quality increased. He goes on to state that the effect of Japanese firms on UK industrial structure has been mostly to the UK's advantage (Dunning, 1984).

The studies that explored the relationships between exports and inward FDI also reported positive outcomes. Pain and Wakelin (1998) argue that even though the impact of FDI varies from place to place, in general, inward FDI has a positive impact on trade. According to their research, the net inward investment into the UK had a significant effect on export performance. Liou (1993) who examined FDI in the US also reported that many state 
governments view inward FDI as a top priority for promoting their economic development. In addition to those findings, the positive impact of inward FDI was also reported for developing countries (Misser 2001).

\subsection{Home Country Impact}

Some researchers have written about a shrinking middle class and the resultant income inequality caused by the loss of manufacturing jobs as companies relocate production elsewhere (Davis \& Huston, 1992; Iganski \& Payne, 1999). However, compared with numerous studies on the impact of inward FDI on host countries, there are fewer studies on the impact of outward FDI on home countries. Moreover, compared with the relatively positive views on inward FDI, there is a diversity of opinions on the impact of outward FDI. Some view outward FDI as having a negative impact on trade and employment. Barrell and Pain (1997) reported a negative relationship between outward FDI and net trade performance. However, their study did not support the idea that outward FDI relates to a drop in domestic employment. However, Blomström, Fors and Lipsey (1997) found that in the case of the US, more outward FDI is associated with lower employment at home. They argue that this is because US firms relocate the more low skill and labor intensive parts of the production process to labor abundant countries. Other studies show that, although the activity may not directly help the national economy, outward FDI can lead to positive developments for corporations. Lu and Beamish's (2001) investigation of 164 Japanese small and medium-sized firms found that the positive impact of internationalization on performance extends primarily from the extent of a firm's FDI activity. Our study used twenty years on data on FDI outflows to examine the impact on the Japanese manufacturing sector and economy in general.

\subsection{Data And Methodology}

We collected the data mainly from three resources: the Statistic Yearbook by United Nation's Statistic Bureau, Japan Statistic Yearbook by the Statistic Bureau, and the FDI white paper by JETRO (Japan External Trade Organization). The period which the data covers is from 1980 to 1999. The description of the variables used to investigate 'hollowing out' is as follows:

\begin{tabular}{|l|l|}
\hline gdshrma: & Share of manufacturing sectors in GDP \\
ratioma: & Share of manufacturing sectors in employment \\
lnfdima: & Natural log of Manufacturing Outward FDI \\
inflation: & Inflation (\%) \\
exchang: & Foreign exchange rate $(Y / \$)$ \\
ratwgma: & Ratio of annual wage of manufacturing sectors to average wage \\
lestma: & Natural log of the number of establishments in the manufacturing sector \\
lexp: & Natural log of value of export. (Y) \\
\hline
\end{tabular}

We will apply statistics and time series econometric modeling techniques to investigate the hollowing out phenomenon. Specifically, we will use a distributed lag model with lagged independent variables. The models used to carry out econometric procedures are:

Dependent Variables $=$ Manufacturing share of (1) GDP (2) Employment (3) FDI Depependent variables (\#1-3) $=\beta_{0}+\beta_{1}$ inflation $_{t}+\beta_{2}$ inflation $_{t-1}+\beta_{3}$ exchang $_{t}+\beta_{4}$ exchang $_{t-1}+\beta_{5}$ ratwgma $_{t}+$ $\beta_{6}$ ratwgma $_{\mathrm{t}-1}+\beta_{7}$ lestma $_{\mathrm{t}}+\beta_{8}$ lestma $_{\mathrm{t}-1}+\beta_{9}$ lexp $_{\mathrm{t}}+\beta_{10}$ lexp $_{\mathrm{t}-1}+\mathrm{u}_{\mathrm{t}}$

\subsection{Dependent Variables}

Our particular focus will be on the variables below. The first three are used in our econometric models. The last two will be investigated separately in the section on the overall impact of 'hollowing out: 
- $\quad$ Share of manufacturing in GDP

- $\quad$ Share of employment in manufacturing sectors

- Value of outward FDI of manufacturing

- Unemployment

- Labor productivity

If 'hollowing-out' has been occurring, the manufacturing sector's share of GDP should show a significant decrease over time. This would probably be due to Japanese firms producing more and more manufacturing goods overseas. In the same way, if manufacturing operations continue relocating overseas, we would expect a drop in the manufacturing share of total employment. We also expect the value of outward FDI to show an increasing trend.

\subsection{Independent Variables}

Since some have argued that the increasing FDI outflow is being accelerated by yen appreciation and the increasing costs of labor and land, we included the wage rates, the inflation rate and the exchange rate as explanatory variables. Since exports have been an important driving force for the Japanese economy, we also included the value of exports to see if its performance affects the 'hollowing out' phenomenon. We used the number of establishments of manufacturing firms as an indication of level of manufacturing activities.

\subsection{Econometric Procedures}

In addition to examining the descriptive statistics, we used analysis of variance (anova) to test for significant differences between the means different variables. We also used a distributed lagged model along with autoregression techniques. Before using autoregression to test the time series data, we carried out a number of adjustments to the variables:

- $\quad$ Tested the variables for 'unit root problems' using the Dickey-Fuller test

- $\quad$ Transformed some variable in the time series using 'first difference'.

- $\quad$ Checked for serial correlations in the models with the Durvin's alternative test.

- $\quad$ Due to the smaller sample size, used the Prais-Winstern technique to correct for serial correlation.

- $\quad$ Obtained serial correlation-robust standard errors for the betas with Prais-Winstern.

- After running autoregression, checked for the joint significance of the current and lagged years ( $\left.t_{\text {and }} t_{-1}\right)$.

\subsection{Analysis and Evaluation}

Before carrying out the econometric modeling techniques, we can get a perspective on the 'hollowing out' phenomenon using some descriptive statistics. The first question we want to address is whether or not 'hollowing out' of the manufacturing sector has been happening in Japan? We first examined the overall trend of the key 'hollowing out' variables over a twenty year period. In examining the manufacturing share of GDP, we see that it held steady at around $30 \%$ for the first ten years (table 1). However, since the early 1990 s, we see a steady decline in the manufacturing share of GDP. This is a clear indication that the manufacturing sector's contribution to the overall strength of the domestic economy has declined considerably.

The manufacturing share of total employment held steady at around $25 \%$ until the end of the bubble economy (table 1). However, in the post-bubble, there has been a steady decline to about $20 \%$. This provides evidence that fewer people have been working in the manufacturing sectors.

The manufacturing share of outgoing foreign direct investment (FDI) was approximately 26\% in 1980 (table 1). The values have gone up and down since then but the overall trend has been upward. We see that starting with the period of the bubble economy (1988-1990), there has been was a surge in manufacturing FDI as the yen strengthened and average wages rose. During the post-bubble period (1990s), manufacturing outward FDI continued to rise before leveling off and then rising sharply again at the end of the 1990s (table 1). There clearly appears to be some significant changes in the key 'hollowing out' factors over the twenty-year period. 
Table 1: Twenty-Year Trend of Hollowing Out Factors

\begin{tabular}{|c|c|c|c|}
\hline Year & $\begin{array}{c}\text { Manufacturing Share } \\
\text { Of GDP } \\
(\%) \\
\end{array}$ & $\begin{array}{c}\text { Manufacturing Share } \\
\text { Of Employment } \\
(\%) \\
\end{array}$ & $\begin{array}{c}\text { Manufacturing Share } \\
\text { Of Outward FDI } \\
(\%) \\
\end{array}$ \\
\hline 1980 & 29.24 & 24.69 & 38.05 \\
\hline 1981 & 28.96 & 24.82 & 26.12 \\
\hline 1982 & 29.00 & 24.48 & 27.48 \\
\hline 1983 & 29.05 & 24.52 & 32.58 \\
\hline 1984 & 29.76 & 24.94 & 25.22 \\
\hline 1985 & 29.55 & 25.02 & 19.78 \\
\hline 1986 & 29.20 & 24.67 & 17.50 \\
\hline 1987 & 29.00 & 24.11 & 23.79 \\
\hline 1988 & 29.20 & 24.19 & 29.73 \\
\hline 1989 & 28.89 & 24.22 & 24.38 \\
\hline 1990 & 29.08 & 24.08 & 27.60 \\
\hline 1991 & 29.00 & 24.34 & 29.94 \\
\hline 1992 & 27.98 & 24.38 & 29.77 \\
\hline 1993 & 26.80 & 23.72 & 31.13 \\
\hline 1994 & 24.47 & 23.18 & 33.90 \\
\hline 1995 & 24.68 & 22.55 & 37.44 \\
\hline 1996 & 24.32 & 22.28 & 43.10 \\
\hline 1997 & 22.88 & 21.99 & 36.22 \\
\hline 1998 & 22.00 & 21.22 & 30.33 \\
\hline 1999 & 21.56 & 20.81 & 63.64 \\
\hline
\end{tabular}

\subsection{Pre-Bubble \& Post-Bubble Comparisons}

In order to investigate the trends further, we compared the 'hollowing out' factors for the two periods which mirror drastic changes in Japan's domestic economy. We used analysis of variance (anova) to test for significant differences in the means of the factors for the pre-bubble and post-bubble periods. We can see in table 2 that there was a significant difference for all three factors.

The manufacturing sector's share of GDP and employment has gone down in the post-bubble period. On the other hand, its share of outward FDI has gone up over the same period. The descriptive statistics above clearly indicate that, in general, there is some element of truth about the 'hollowing out' phenomenon in Japan. We will now proceed to the econometric techniques used to analyze the impact of various factors that might have contributed to 'hollowing out'.

Table 2: Pre-Bubble, Post-Bubble Comparison of Means (ANOVA).

\begin{tabular}{|l|c|c|c|}
\hline \multicolumn{1}{|c|}{ Variables } & $\begin{array}{c}\mathbf{1 9 8 0 - 1 9 8 9} \\
\text { Mean (Stdv) }\end{array}$ & $\begin{array}{c}\text { 1990-1999 } \\
\text { Mean (Stdv) }\end{array}$ & Significance \\
\hline Manufacturing share of GDP & $.292(.003)$ & $.253(.028)$ & $* * *$ \\
\hline Manufac. Share of employment & $.246(.003)$ & $.229(.013)$ & $* * *$ \\
\hline Manufac. Share of FDI-outward & $27.34(.594)$ & $28.26(.406)$ & $* *$ \\
\hline
\end{tabular}

+ not significant. Significant at $* \mathrm{p}<.05 * *<.01 * * *<.001$ 


\subsection{Autoregression Results Of The Distributed Lagged Model}

In this section we focus on the domestic factors which are argued to have an impact on 'hollowing out' trends. The factors usually mentioned in the literature include inflation, wage levels, exchange rates, number of firms, and export activity (Hirono, 1996; Ishiyama, 1999). The distributed lagged model used for the econometric procedures was:

Dependent Variables $=$ Manufacturing share of (1) GDP (2) Employment (3) FDI Depependent variables (\#1-3) $=\beta_{0}+\beta_{1}$ inflation $_{t}+\beta_{2}$ inflation $_{t-1}+\beta_{3}$ exchang $_{t}+\beta_{4}$ exchang $_{t-1}+\beta_{5}$ ratwgma $_{t}+$ $\beta_{6}$ ratwgma $_{\mathrm{t}-1}+\beta_{7}$ lestma $_{\mathrm{t}}+\beta_{8}$ lestma $_{\mathrm{t}-1}+\beta_{9}$ lexp $_{\mathrm{t}}+\beta_{10}$ lexp $_{\mathrm{t}-1}+\mathrm{u}_{\mathrm{t}}$

We see a significant relationship between lower inflation levels and an increase in the sector's share of GDP (table 3). There was no significant impact for the lagged variable (t-1) for inflation. Both the current and lagged variable for exchange rates appear to not have a significant impact either. The remaining variables are closely linked to periods of dynamic activity in the manufacturing sector. Higher current and lagged manufacturing wage levels reflect the period when the sector was more active. We also see that a larger number of manufacturing firms and higher levels of exports support an expanding manufacturing sector. Overall, greater exports, more manufacturing firms and higher wage levels are factors associated with increasing economic activity and a growing manufacturing sector.

Table 3: Autoregression of Hollowing Out Factors

\begin{tabular}{|c|c|c|c|}
\hline \multirow[b]{2}{*}{ Factors } & \multicolumn{3}{|c|}{ Manufacturing Share of } \\
\hline & $\mathbf{G D P}_{\mathrm{t}}$ & Employment $_{t}$ & $\mathbf{F D I}_{\mathbf{t}}$ \\
\hline $\begin{array}{l}\text { Inflation }_{t} \\
\text { Lag-inflation }_{t-1}\end{array}$ & $\begin{array}{l}-.0056 * * * \\
(.001) \\
.0006+ \\
(.001)\end{array}$ & $\begin{array}{c}-.0006+ \\
(.002) \\
-.0034 * \\
(.001)\end{array}$ & $\begin{array}{l}-.0965+ \\
(.106) \\
-.1403 * \\
(.048)\end{array}$ \\
\hline $\begin{array}{l}\text { Exchang-rate }_{t} \\
\text { Lag-exchang-rate }_{t-1}\end{array}$ & $\begin{array}{c}.00002+ \\
(.0001) \\
-.00008+ \\
(.0001)\end{array}$ & $\begin{array}{l}.00017 * \\
(.0001) \\
.00024 * \\
(.0001)\end{array}$ & $\begin{array}{c}.00427+ \\
(.006) \\
.00337+ \\
(.006)\end{array}$ \\
\hline $\begin{array}{l}\text { Manufac. Wage ratio }_{t} \\
\text { Lag-Man.wage ratio }_{t-1}\end{array}$ & $\begin{array}{c}.483 * * \\
(.097) \\
.601 * * * \\
(.093)\end{array}$ & $\begin{array}{l}-.006+ \\
(.083) \\
.909 * * \\
(.117)\end{array}$ & $\begin{array}{c}18.51 * \\
(5.25) \\
-3.54+ \\
(3.59)\end{array}$ \\
\hline $\begin{array}{l}\text { Ln(Num.of Man. firms) }{ }_{t} \\
\text { Lag-Ln(Num.of Man. Firms estma)t-1 }\end{array}$ & $\begin{array}{l}.074 * * \\
(.015) \\
.064 * \\
(.023)\end{array}$ & $\begin{array}{c}-.007+ \\
(.022) \\
.121 * * \\
(.028)\end{array}$ & $\begin{array}{l}2.54 * \\
(.984) \\
.376+ \\
(1.78)\end{array}$ \\
\hline $\begin{array}{l}\operatorname{Ln}(\text { Eports })_{t} \\
\text { Lag-In(Exports)t-1 }\end{array}$ & $\begin{array}{l}-.018+ \\
(.021) \\
.031 * \\
(.012) \\
\end{array}$ & $\begin{array}{c}-.084 * * \\
(.015) \\
-.004+ \\
(.013) \\
\end{array}$ & $\begin{array}{c}-2.43+ \\
(1.13) \\
-.542+ \\
(1.75) \\
\end{array}$ \\
\hline Constant & -1.775 & -1.477 & -37.123 \\
\hline R-Squared & 0.98 & 0.94 & 0.94 \\
\hline
\end{tabular}

+ not significant. Significant at $* \mathrm{p}<.05 * *<.01 * * *<.001$

Employment levels are often mentioned in the discussion of the 'hollowing out' phenomenon. Here again, lower levels of inflation, higher wage levels, and a greater number of firms are factors indicating the sector's growing share of employment. For exchange rates, we see here that a stronger yen is associated with an increase in the manufacturing sector's share of employment. This may seem counter intuitive since higher exchange rates usually push down exports and could threaten jobs. However, since we are only including the yen-dollar exchange rate, we 
don't have a full picture of the exchange rate dynamics. Moreover, during the very active years of the economic bubble, the yen remained strong.

Outward FDI is the factor most strongly associated with 'hollowing out'. We observe that lower inflation levels have a positive impact on the level of FDI. This is most likely because of the lower cost of borrowing money for foreign investments and production activities. The higher manufacturing wage levels also seem to spur firms to increase their outward FDI activities. An increase in the number of manufacturing firms indicates a more active sector but also increase the number of potential participants in FDI. Interestingly, although the result for exports was not significant, there is a negative correlation between exports and outward FDI. The results above are in line with expectations.

Since we used lagged independent variables, we decided to confirm the joint impact of the current $(t)$ and lagged ( $\mathrm{t}-1)$ factors on the dependent variables. Table 4 (appendix) show the combined impact of the factors. The joint impacts of the variables in the autoregression are in line with the results in table 3 above. The exchange rate factor provided the least explanatory power. However, inflation levels, wage rates, the number of firms, and export levels indicate a strong link to 'hollowing out' factors in the manufacturing sector.

\subsection{Perspectives On The 'Hollowing Out' Outcomes}

There is still some uncertainty in some quarters as to the nature of the impact of the hollowing out of the manufacturing sector. In Japan, some have argued that an over dependence on manufacturing exports prevent other sectors from developing and also holds down the productivity of the sector (Chowdhury 1987; Terasaki and Yamauchi 1996). These researchers believe that there is a need for drastic structural adjustments and the service sector needs to absorb more of the workforce. Others argue that with a weak manufacturing sector, income levels and aggregate demand will drop, preventing any sustained economic growth (Caulkin 1983; Schnorbus and Giese 1987; Davis and Huston 1992). We again used descriptive statistics and ANOVA to explore these issues.

Chart 1 (appendix) compares employment activity in both the manufacturing and non-manufacturing sector over the twenty-year period (1988-1999). While manufacturing employment has held steady, non-manufacturing employment has significantly increased. At the same time, overall unemployment has also jumped over the period. Chart 2 (appendix) shows the twenty-year trend for labor productivity in the manufacturing and non-manufacturing sectors. Manufacturing labor productivity clearly increased steadily until the final years of the 1990s. Nonmanufacturing labor productivity also improved drastically and then slowed to around the same level as the manufacturing sector in the late 1990s. Moreover, our analysis of variance (anova) examination of the variables (table 5, appendix) indicates a significant difference between the pre-bubble and post-bubble periods for all the variables except manufacturing employment.

\subsection{Conclusion}

The issue of the 'hollowing out' of the manufacturing sector in Japan continues to be intensely debated. The long ten-year recession has forced both policy makers and corporate executives to seriously examine past strategies in order to formulate new and effective approaches to economic revitalization. The goal of this paper was to examine and clarify the outcome and factors affecting the 'hollowing out' phenomenon in Japan.

Our analysis supports the view that the manufacturing sector is weakening in Japan. This is especially clear when we compare the pre-bubble (1980-1989) to the post-bubble (1990-1999) developments. There has been a significant decline in the manufacturing sector's share of gross domestic product and employment (table 1). There was also a significant jump in outward FDI. In addition to the loss of jobs, there is concern about the level of capital outflow.

Our examination of the factors impacting the 'hollowing out' phenomenon was also instructive. Lower inflation, high exports, active firm formation and strong wage levels were associated with a more dynamic manufacturing sector. It is no surprise that these were the conditions before the long post-bubble recession. Our investigation 
of the 'hollowing out' outcomes in the economy also provided some answers. There is some structural economic adjustment underway. The non-manufacturing sector is absorbing greater number of workers even as unemployment continues to rise (chart 1,appendix ). At the same time, the manufacturing and non manufacturing sectors have seen steady improvement in labor productivity. However, the productivity gap between the sectors has narrowed considerably. This could indicate that the service sector is playing a greater role in domestic economic activity. Nevertheless, the persistent unemployment and long recession point to the need for policies which will invigorate both sectors if Japan is to return to a strong growth path.

This paper adds to the body of research on de-industrialization in mature economies. It uses more recent data than previous studies of the phenomenon in Japan and supports the view that the manufacturing sector has been significantly weakened. The continued outflow of Japanese FDI to areas like China and S.E. Asia will only accelerate that development. There is a need for future studies to examine the role and impact of inward FDI in Japan. It will be interesting to see whether or not governmental policies, foreign capital, and new business strategies will help this economy regain its prominence in the world.

\section{Appendix: Tables and Charts}

Table 4: Combined Impact of Factors (Joint Effects)

\begin{tabular}{|l|c|c|c|}
\hline & \multicolumn{2}{|c|}{ Manufacturing sector of } \\
\hline Factors & Share of GDP & Share of employment & FDI \\
\hline Inflation & $-.005 * *$ & $-.004+$ & $-.237 *$ \\
& $(.001)$ & $.002)$ & $.099)$ \\
\hline Exchange rate & $-.00006+$ & $\left(.00047^{* *}\right.$ & $(.0058)$ \\
\hline Manu wage ratio to av- & $(.00013)$ & $.604 * *$ & $14.97 *$ \\
erage wage & $1.085 * * *$ & $(.125)$ & $(5.36)$ \\
\hline Number of establish- & $(.117)$ & $.115 * *$ & $2.91 *$ \\
ments & $.137 * * * 1.27)$ \\
\hline Exports & $(.018)$ & $(.020)$ & $-2.97+$ \\
& $.013+$ & $-.088 * *$ & $(1.98)$ \\
\hline
\end{tabular}

+ not significant. Significant at $* \mathrm{p}<.05 * *<.01 * * *<.001$

Table 5 (anova): Pre-Bubble, Post-Bubble Comparisons

\begin{tabular}{|l|c|c|c|}
\hline \multicolumn{1}{|c|}{ Variables } & $\begin{array}{c}\text { Year: 1980-1989 } \\
\text { Mean (stdv) }\end{array}$ & $\begin{array}{c}\text { Year: 1990-1999 } \\
\text { Mean (stdv) }\end{array}$ & Significance \\
\hline Ln Manufacturing Employment & 7.26 & 7.29 & + \\
\hline Ln Non-manufacturing Employment & $(.03)$ & $8.05)$ & $* * *$ \\
& 8.38 & $(.03)$ & $*$ \\
\hline Ln Unemployment & $(.03)$ & 5.27 & $(.30)$ \\
\hline Ln Manufacturing Productivity & $(.13)$ & 15.92 & $* * *$ \\
& 15.65 & $(.02)$ & $* * *$ \\
\hline
\end{tabular}

+ not significant. Significant at $* \mathrm{p}<.05 * *<.01 * * *<.001$ 
Chart 1: Twenty-Year Employment Trends

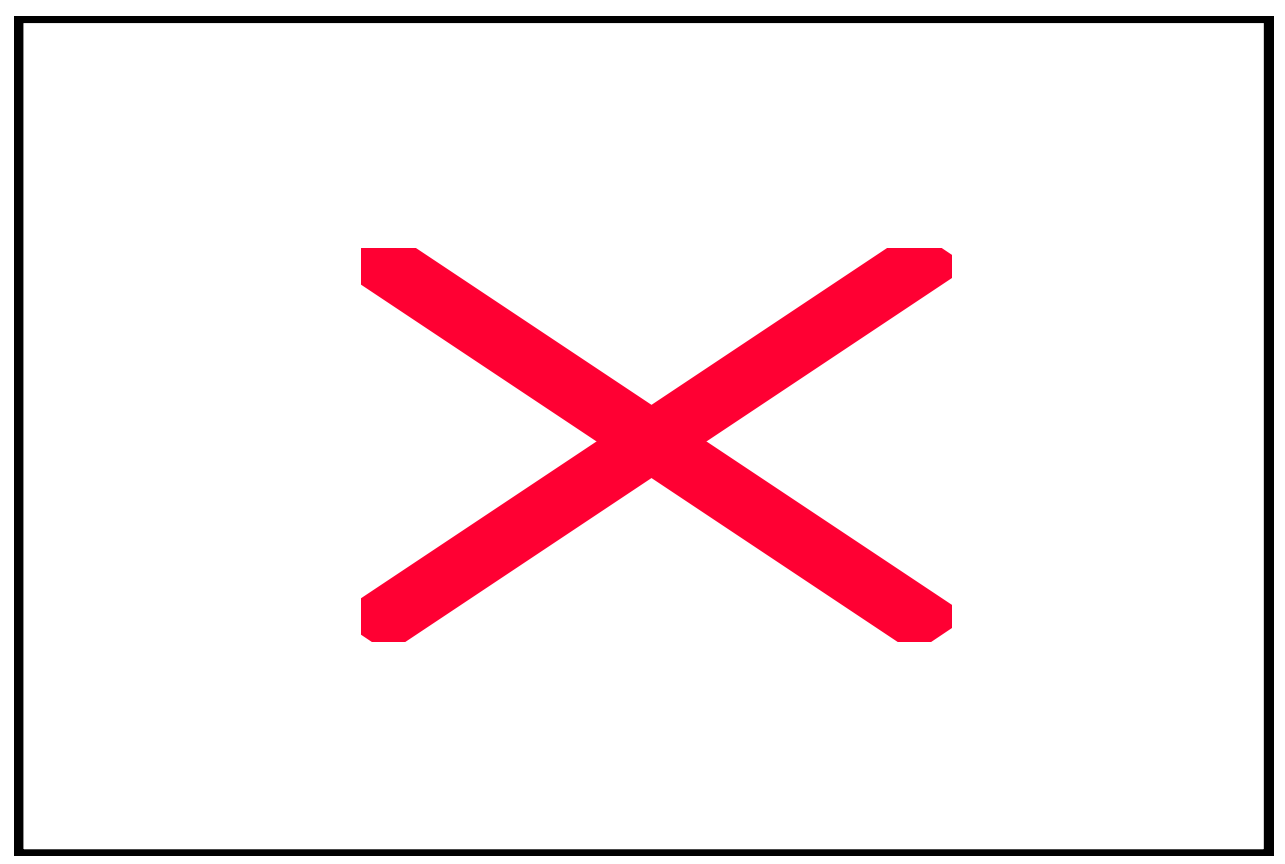

Chart 2: Twenty-Year Trend for Labor Productivity

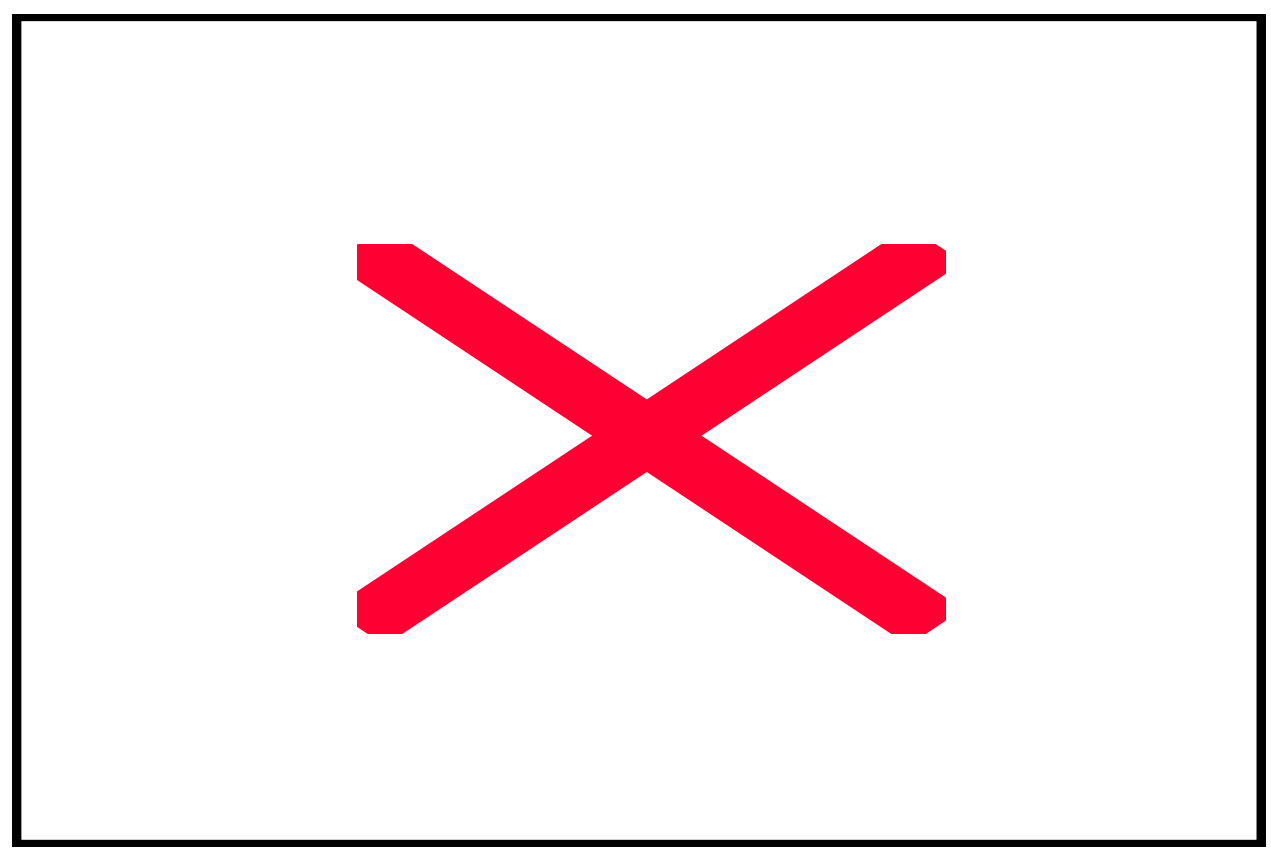


Table 6: Correlations between independent variables, including lagged variables.

\begin{tabular}{|c|c|c|c|c|c|c|c|c|c|c|}
\hline & inflation $_{t}$ & inflation $_{t-1}$ & $\Delta$ exchang ${ }_{t}$ & $\Delta \operatorname{exchang}_{\mathrm{t}-1}$ & $\Delta$ ratwgma $_{t}$ & $\Delta$ ratwgmat $_{t-1}$ & lestma $_{t}$ & lestmat $_{t-1}$ & $\Delta \operatorname{lexp}_{\mathrm{t}}$ & $\operatorname{lexp}_{\mathrm{t}-1}$ \\
\hline inflation $_{t}$ & 1.0000 & & & & & & & & & \\
\hline inflation $_{t-1}$ & 0.6495 & 1.0000 & & & & & & & & \\
\hline$\Delta$ exchang $_{t}$ & 0.3162 & 0.0083 & 1.0000 & & & & & & & \\
\hline$\Delta$ exchang $_{\mathrm{t}-1}$ & 0.4356 & 0.3452 & 0.3700 & 1.0000 & & & & & & \\
\hline$\Delta$ ratwgma $_{t}$ & -0.2156 & -0.4335 & 0.4300 & 0.2718 & 1.0000 & & & & & \\
\hline$\Delta$ ratwgma $_{t-1}$ & 0.4139 & -0.0253 & 0.5285 & 0.6126 & 0.3339 & 1.0000 & & & & \\
\hline lestma $_{t}$ & 0.5635 & 0.5128 & -0.2805 & -0.1648 & -0.5580 & -0.2209 & 1.0000 & & & \\
\hline lestma $_{t-1}$ & 0.5231 & 0.4787 & -0.2390 & -0.3618 & -0.4531 & -0.3569 & 0.8761 & 1.0000 & & \\
\hline$\Delta \operatorname{lexp}_{\mathrm{t}}$ & 0.4548 & -0.1339 & 0.7608 & 0.3778 & 0.3606 & 0.6920 & -0.0506 & -0.0659 & 1.0000 & \\
\hline $\operatorname{lexp}_{\mathrm{t}-1}$ & 0.5693 & 0.5294 & 0.2673 & 0.7620 & -0.0740 & 0.5821 & 0.0595 & -0.1267 & 0.1944 & 1.0000 \\
\hline
\end{tabular}

Table 7: Correlations between non-lagged independent variables.

\begin{tabular}{|l|c|c|c|c|c|}
\hline & inflation $_{\mathbf{t}}$ & $\Delta$ exchang $_{\mathbf{t}}$ & sratwgma $_{\mathbf{t}}$ & lestma $_{\mathbf{t}}$ & .lexp $_{\mathbf{t}}$ \\
\hline inflation $_{\mathbf{t}}$ & 1.0000 & & & & \\
\hline$\Delta$ exchang $_{\mathbf{t}}$ & 0.3162 & 1.0000 & & & \\
\hline$\Delta$ ratwgma $_{\mathbf{t}}$ & -0.2156 & 0.4300 & 1.0000 & & \\
\hline lestma $_{\mathbf{t}}$ & 0.5635 & -0.2805 & -0.5580 & 1.0000 & \\
\hline Ilexp $_{\mathbf{t}}$ & 0.4548 & 0.7608 & 0.3606 & -0.0506 & 1.0000 \\
\hline
\end{tabular}

\section{Bibliography}

1. Barrell, Ray; Pain, Nigel "Foreign direct investment technological change, and economic growth within Europe," Economic Journal: The Journal of the Royal Economic Society, November 1997 p.1770-1985

2. Barrell, Ray; Pain, Nigel "Domestic Institutions, agglomerations and foreign direct investment in Europe," European Economic Review, 1999, p.925

3. Blomström, Magnus; Fors, Gunnar; Lipsey, Robert E. "Foreign Direct Investment and Employment: Home country experience in the United States and Sweden," The Economic Journal: The Journal of the Royal Economic Society, November 1997 p.1787-1797

4. Brada, J. C., I. Singh, et al. (1994). "Structural change and deindustrialization after 1988." Eastern European Economics 32: 38-48.

5. $\quad$ Caulkin, S. (1983). "Manufacturing's Last Stand." Management Today: 50-61.

6. $\quad$ Chowdhury, A. (1987). "Japan: A Move Towards Deindustrialisation?" Asian Finance 13: 33-56.

7. $\quad$ Crafts, N. (1996). "Deindustrialisation and economic growth." Economic Journal: The Journal of the Royal Economic Society 106: 172-183.

8. $\quad$ Davis, J. C. and J. H. Huston (1992). "The shrinking middle-income class: A multivariate analysis." Eastern Economic Journal 18: 277-285.

9. Dreyfack, K. and O. Port (1986). "Even American Knowhow Is Headed Abroad." Business Week(Industrial/Technology Edition): 60-64.

10. Dunning, J. H. “Japanese Investment in UK Industry: Trojan Horse or New Catalyst for Growth?” Multinational Business, 1984, p.1-6

11. Feinstein, C. (1999). "Structural change in the developed countries during the twentieth century." Oxford Review of Economic Policy 15: 35-56.

12. Hirono, Ryokichi “Japan's Direct Investment Overseas; Performance, Issues, and Prospect, 1951-2000,” Management Japan, Spring 1996, p.3-11

13. Iganski, P. and G. Payne (1999). "Socio-economic re-structuring and employment: The case of minority ethnic groups." British Journal of Sociology 50: 195-215.

14. Ishiyama, Yoshiihde "Is Japan Hollowing Out" p. 241-260 in Dennise J. Encarnation edited, Japanese Multinationals in Asia 1999

15. Japan Statistical Bureau, Japan Statistical Yearbook, 1981-2002

16. JETRO, JETRO Foreign Direct Investment White Paper ${ }_{2}$ 1981-2002

17. Liou, K. T. "Foreign direct investment in the United States: Trends, motives, and the state experience," American Review of Public Administration, 1993, p1-17

18. Lu, J.W.; Beamish, P.W. "The internationalization and performance of SMEs," Strategic Management Journal, Jun/Jul 2001, p565-586

19. Misser, F. "Madagascar: Africa's giant island awakens,” African Business, Jul/Aug 2001, p.12-15 
20. Modic, S. J. and D. H. Trautlein (1985). "Perils of Deindustrialization (Part 1)/Where Have All the Factories Gone?" Industry Week 226: 25-29.

21. Pain, Nigel; Wakelin, Katharine "Export performance and the Role of Foreign Direct Investment," The Manchester School Supplement, 1998, p62-70

22. Peck, J. E. (1996). "The effect of deindustrialization on area income: Myth vs. reality." Economic Development Review 14: 31-36.

23. Radulescu, Marian "Towards a Strategy for Increasing Foreign Direct Investment Impact on the Romanian Economy," Centre For Economic Reform and Transformation, November 1996, p.7

24. $\quad$ Robinson, A. (1983). "Latin America: The IMF vs. the People." Euromoney(IMF Special Issue): 90-93.

25. Schnorbus, R. H. and A. S. Giese (1987). "Is the Seventh District's Economy Deindustrializing?" Economic Perspectives 11: 3-9.

26. Spilimbergo, A. (1998). "Deindustrialization and trade." Review of International Economics 6: 450-460.

27. Terasaki, M. and K. Yamauchi (1996). "New opportunities for the manufacturing industry in the advanced industrialized countries." Management Japan 29: 12-17.

28. The Nikkei Weekly, "Hollowing-out trend accelerates," February 25, 2002

29. Trowbridge, A. B. (1985). "Defusing Deindustrialization." Industry Week 227: 61,64.

30. The UN Statistical Yearbook, 1981-2001

Notes 


\section{Notes}

